\title{
PENGARUH PERPUTARAN PERSEDIAAN DAN PERPUTARAN PIUTANG TERHADAP PROFITABILITAS
}

\author{
Alfiatun Jennah ${ }^{1}$, Rama Yuli ${ }^{2}$ \\ ${ }^{1}$ STIE Muhammadiyah Jakarta, alfiatunjennah30@gmail.com \\ ${ }^{2}$ STIE Muhammadiyah Jakarta, ramayuli886@yahoo.co.id
}

\begin{abstract}
ABSTRAK
Kinerja perusahaan yang baik terlihat pada kinerja keuangan perusahaan yang menggunakan aturan-aturan pelaksanaan keuangan secara baik dan benar. Penelitian ini bertujuan untuk mengetahui antara perputaran persediaan dan perputaran piutang terhadap profitabilitas secara parsial dan simultan pada perusahaan manufaktur yang terdaftar di Bursa Efek Indonesia periode 2012-2017. Penelitian ini dilakukan untuk meningkatkan profitabilitas perusahaan dan menjadikan perusahaan tersebut sukses dalam mencapai tujuan tanpa ada tindakan menyimpang. Jenis penelitian ini bersifat deskriptif kuantitatif dengan menggunakan data sekunder yang di ambil secara Simple Random Sampling yaitu cara pemilihan sampel dimana anggota dari populasi dipilih satu persatu secara random atau acak (semua mendapatkan kesempatan yang sama untuk di pilih) dimana jika sudah dipilih tidak dapat dipilih kembali. Analisis data yang digunakan adalah SPSS versi 19 karena model penelitian menggunakan data sekunder. Analisis data yang digunakan adalah SPSS versi 19 karena model penelitian menggunakan data sekunder. Data tersebut kemudian di analisis menggunakan Uji Statistik Deskriptif, Uji Asumsi Klasik, Uji Analisis Regresi Linear Berganda, Uji Hipotesis dan Uji Koefisien Determinasi. Hasil analisa data membuktikan bahwa perputaran persediaan dan perputaran piutang berpengaruh signifikan terhadap profitabilitas perusahaan. Oleh karena itu perusahaan perlu meningkatkan perputaran persediaan dan perputaran piutang agar lebih meningkatkan profitabilitas perusahaan.
\end{abstract}

Kata Kunci: Perputaran Persediaan, Perputaran Piutang dan Profitabilitas

\begin{abstract}
The best company performance is seen in the company's financial performance by using the rules of financial implementation properly and correctly. This study aims to determine between inventory turnover and accounts receivable turnover towards profitability partially and simultaneously on manufacturing companies listed on the Indonesia Stock Exchange in the period 2012-2017. This research was conducted to increase the company's profitability and make the company successful in achieving its goals without any deviant actions. This type of research is quantitative descriptive using secondary data taken by Simple Random Sampling which is a sample selection where members are randomly selected randomly (all get the same opportunity to choose) where if it has been selected it cannot be selected again. The data analysis used is SPSS version 19 because the research model uses secondary data. The data is then analyzed using The Descriptive Statistical Test, Classic Assumption Test, Multiple Linear Regression Analysis Test, Hypothesis Test and Determination Coefficient Test. The results of the study prove that inventory turnover and accounts receivable turnover have a significant effect on company profitability. Therefore, companies need to increase inventory turnover and accounts receivable turnover in order to further increase the company's profitability.
\end{abstract}

Keywords: Inventory Turnover, Accounts Receivable Turnover and Profitability 


\section{JURNAL AKUNTANSI, Vol. 8, No. 2, November (2019)}

\section{PENDAHULUAN}

Bagi perusahaan masalah profitabilitas sangatlah penting. Bagi pemimpin perusahaan profitabilitas digunakan untuk melihat seberapa besar kemajuan atau berhasil tidak perusahaan yang dipimpinnya. Sedangkan bagi karyawan perusahaan apabila semakin tinggi keuntungan yang diperoleh perusahaan tempat kerjanya, maka ada kesempatan baginya untuk dapat kenaikan gaji. Menurut Sofyan (2010:304), profitabilitas menggambarkan kemampuan perusahaan mendapatkan laba melalui semua kemampuan dan sumber yang ada seperti kegiatan penjualan, kas, modal, jumlah karyawan, jumlah cabang, dan sebagainya. Profitabilitas menggambarkan kemampuan perusahaan untuk menghasilkan laba dengan menggunakan seluruh modal yang dimiliki. Profitabilitas suatu perusahaan merupakan salah satu dasar penilaian kondisi suatu perusahaan, untuk itu dibutuhkan suatu alat analisis agar dapat menilainya. Alat analisis yang dimaksud adalah rasio-rasio keuangan.

Fluktuasi Return On Asset (ROA) dari masing-masing perusahaan manufaktur. Dapat dilihat pada PT. HM Sampoerna Tbk di tahun 2014 menunjukkan tingkat profitabilitas tertinggi dari beberapa tahun pengamatan yaitu sebesar 0,417. Ini berarti pada tahun 2014 PT. HM Sampoerna Tbk memiliki kinerja perusahaan yang baik karena dapat menghasilkan profitabilitas yang tinggi diantara perusahaan lainnya. Tingkat profitabilitas terendah dapat dilihat pada PT. Alumindo Lifhgt Metal Industry Tbk di tahun 2014 yaitu hanya sebesar 0,001.

Sektor manufaktur yang sebagian besar komponen pembentuknya terdiri dari indeks consumer, industri dasar, dan aneka industri, naik 9\% sejak awal tahun hingga Juli 2013. Industri manufaktur diproyeksikan akan tumbuh mencapai 7,1\% pada 2013 meskipun kondisi perekonomian di Amerika Serikat (AS) dan Uni Eropa masih diwarnai ketidakpastian. Berbagai faktor negatif seperti kenaikan gas, kenaikan tarif dasar listrik, upah minimum pekerja, infrastruktur yang belum dapat diandalkan, serta, lemahnya nilai tukar, tetap tidak menganggu pertumbuhan sektor ini. "Kinerja sektor industri manufaktur pada 2013 tumbuh akibat meningkatnya investasi di sektor otomotif, industri kimia dan semen, industri pupuk. Terjaganya pertumbuhan sektor ini akan berdampak terhadap peningkatan pendapatan perusahaan yang bergerak di sektor manufaktur.

Ada beberapa faktor yang mempengaruhi profitabilitas, diantaranya perputaran persediaan. Menurut Raharjaputra dalam Kun dan Hening (2014), semakin cepat tingkat perputaran persediaan, kemungkinan semakin besar perusahaan akan memperoleh keuntungan. Begitu juga sebaliknya, jika tingkat perputaran persediaannya lambat, maka kemungkinan semakin kecil perusahaan akan memperoleh keuntungan. Di mana menurut Harmono (2011:234) perputaran persediaan menjelaskan sejauh mana persediaan berputar dalam satu tahun dapat diperoleh dari harga pokok penjualan dibagi saldo rata-rata persediaan. Analisis profitabilitas menggambarkan kinerja fundamental perusahaan ditinjau dari tingkat efisiensi dan efektivitas operasi perusahaan dalam memproleh laba.

Pada prinsipnya perputaran persediaan mempermudah atau memperlancar jalannnya operasi perusahaan yang harus dilakukan secara berturut-turut untuk memproduksi barang-barang serta mendistribusikannnya kepada pelanggan. Semakin tinggi perputaran persediaan barang, maka semakin tinggi biaya yang dapat ditekan sehingga semakin besar perolehan laba suatu perusahaan. Sebaliknya, jika semakin lambat perputaran persediaan barang, semakin kecil pula laba yang diperolehnya. Berikut akan disajikan data mengenai perputaran pesediaan.

Seberapa banyak perputaran persediaan tiap tahunnya pada perusahaan manufaktur dapat diamati sebagai berikut, PT. Bentoel Prima pada tahun 2015 menunjukkan perputaran persediaan yang sangat cepat yaitu sebanyak 9,919 kali. Hal ini berarti PT. Indofood CBP Sukses Makmur Tbk mampu mengelola perputaran persediaannya dengan efisien dan efektif sehingga dapat meningkatkan perolehan profitabilitas perusahaan. Namun pada PT. Gudang Garam Tbk menggambarkan kurang mampunya dalam mengelola persediaan secara efektif dan efisien Pada tahun 2015 hanya terjadi perputaran persediaan sebanyak 1,318 kali. Yang berarti persediaan PT. 
Gudang Garam Tbk belum mampu mengelola perputaran persediaan secara efisien dan efektif sehingga tingkat perputaran persediaan pada perusahaan tersebut melambat atau perusahaan terlalu banyak men-stock persediaan di gudang penyimpanan. Hal tersebut menyebabkan munculnya biaya penyimpanan dan biaya pemeliharaan yang dapat menurunkan perolehan profitabilitas perusahaan.

Faktor yang mempengaruhi profitabilitas selain perputaran persediaan adalah perputaran piutang. Menurut Luh Komang dkk, (2014), semakin cepat tingkat perputaran piutang maka semakin tinggi pula tingkat profitabilitas pada perusahaan, karena dengan perputaran piutang yang cepat menyebabkan investasi yang sedikit pada piutang. Dengan kata lain akan lebih cepat menjadi kas yang kemudian digunakan untuk investasi kembali dan dapat meminimalkan risiko kerugian piutang. Perputaran piutang berpengaruh secara langsung terhadap penghasilan yang diperoleh perusahaan. Rasio perputaran piutang memberikan pemahaman tentang kualitas piutang dan kesuksesan dalam penagihan piutang. Putang diharapkan perusahaan mampu meningkatkan pendapatan sehingga akan menghasilkan profitabilitas yang maksimal. Untuk lebih mengetahui permasalahan piutang yang terjadi pada perusahaan manufaktur tersebut.

PT. HM Sampoerna Tbk tahun 2012 memiliki perputaran piutang tercepat diantara semua tahun pengamatan, yaitu sebanyak 67,711 kali. Hal ini menunjukkan bahwa PT. HM Sampoerna Tbk memiliki tingkat perputaran piutang yang cepat dan dapat dikatakan memiliki kemampuan dalam mengelola perputaran piutang sehingga dapat memperoleh profitabilitas yang maksimal. Berbeda dengan PT. Djarum Tbk, pada tahun yang sama yaitu tahun 2013 mengalami perputaran piutang yang sangat lambat yaitu sebanyak 2,004 kali. Ini menandakan bahwa pembayaran dari penjualan kredit yang dilakukan oleh pelanggan terlambat atau panjangnya periode pengumpulan piutang yang ditetapkan oleh perusahaan. Hal tersebut mengakibatkan penurunan perolehan profitabilitasnya.

Selain kedua faktor tersebut, terdapat faktor lain yang mempengaruhi profitabilitas yaitu risiko bisnis. Risiko bisnis menurut Van Horne dan Wachowicz (2013:146) adalah ketidakpastian yang melekat pada operasi fisik perusahaan. Dampaknya diperlihatkan dalam variabilitas penghasilan operasional perusahaan (EBIT). Untuk mengukur risiko bisnis suatu perusahaan dapat digunakan leverage operasi. Variabilitas dasar biaya penjualan dan produksi, tingkat leverage operasi akan memperbesar variabilitas laba operasi, dan akhirnya, risiko bisnis perusahaan. Menurut Keown (2010:120), semakin besar derajat leverage operasi semakin besar variasi labanya dengan persentase perubahan dalam penjualan.

Berdasarkan latar belakang tersebut, penelitian-penelitian terdahulu masih menghasilkan banyak perbedaan, maka perlu dilakukan penelitian kembali tentang pengaruh perputaran persediaan dan perputaran piutang terhadap profitabilitas di Indonesia. Penelitian ini bertujuan untuk menguji dan menemukan bukti secara empiris mengenai pengaruh perputaran persediaan dan perputaran piutang terhadap profitabilitas secara komprehensif.

\section{KAJIAN LITERATUR}

\section{Profitabilitas}

Menurut Agus Sartono (2010:122) menyatakan bahwa profitabilitas adalah kemampuan perusahaan memperoleh laba dalam hubungannya dengan penjualan total aktiva maupun modal sendiri. Profitabilitas suatu perusahaan menunjukkan perbandingan antara laba dengan aktiva atau modal yang menghasilkan laba tersebut.

$$
\mathrm{ROA}=\frac{\text { Net Profit }}{\text { Total Asset }}
$$




\section{JURNAL AKUNTANSI, Vol. 8, No. 2, November (2019)}

\section{Perputaran Persediaan}

Menurut Harrison Jr et.al. (2013:260), perputaran persediaan (inventory turnover) yaitu mengukur berapa kali perusahaan menjual tingkat rata-rata persediaannya selama satu tahun. Perputaran yang cepat menunjukkan kemudahan dalam menjual persediaan, sementara perputaran yang rendah mengindikasi kesulitan dalam menjual persediaan. Besarnya hasil perhitungan persediaan menunjukkan tingkat kecepatan persediaan menjadi kas atas piutang dagang. Rasio ini dihitung sebagai berikut :

$$
\text { Rasio Perputaran Persediaan }=\frac{\text { Harga Pokok Penjualan }}{\text { Rata }- \text { rata Persediaan }}
$$

\section{Perputaran Piutang}

Menurut Bambang Riyanto (2011:90) menyatakan bahwa tingkat perputaran piutang (receivable turn over) dapat diketahui dengan membagi jumlah credit sales selama periode tertentu dengan jumlah rata-rata piutang (average receivable).

$$
\begin{aligned}
& \text { Perputaran } \\
& \text { piutang }
\end{aligned} \quad=\quad \frac{\text { Penjualan }}{\text { Rata-rata piutang }}
$$

\section{Pengembangan Hipotesis}

Menurut Sugiyono (2012:84) menyatakan bahwa: "Hipotesis adalah alternaltif dugaan jawaban yang dibuat oleh peneliti bagi problematika yang diajukan dalam penelitian. Dugaan jawaban tersebut merupakan kebenaran yang sifatnya sementara yang akan diuji kebenarannya dengan data yang dikumpulkan dalam penelitian".

Ha1: Terdapat pengaruh yang signifikan antara perputaran persediaan terhadap profitabilitas perusahaan manufaktur yang terdaftar di BEI.

Ho1: Tidak terdapat pengaruh yang signifikan antara perputaran persediaan terhadap profitabilitas perusahaan manufaktur yang terdaftar di BEI.

Ha2: Terdapat pengaruh yang signifikan antara perputaran piutang terhadap profitabilitas perusahaan manufaktur yang terdaftar di BEI.

Ho2: Tidak terdapat pengaruh yang signifikan antara perputaran piutang terhadap profitabilitas perusahaan manufaktur yang terdaftar di BEI.

Ha3: Terdapat pengaruh yang signifikan antara perputaran persediaan dan perputaran piutang terhadap profitabilitas perusahaan manufaktur yang terdaftar di BEI.

Ho3: Tidak terdapat pengaruh yang signifikan antara perputaran persediaan dan perputaran piutang terhadap profitabilitas perusahaan manufaktur yang terdaftar di BEI.

\section{Kerangka Pikir dan Hipotesis}

Berdasarkan uraian di atas, dapat dibuat suatu kerangka pemikiran teoritis yang menggambarkan variabel-variabel yang mempengaruhi profitabilitas yaitu: 


\section{JURNAL AKUNTANSI, Vol. 8, No. 2, November (2019)}

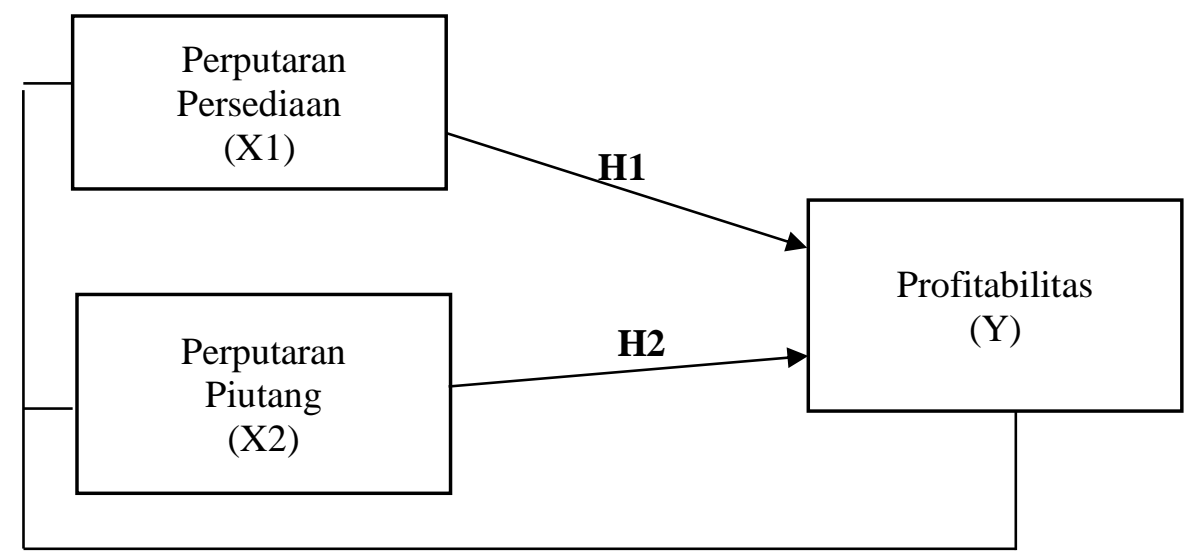

H3

\section{Gambar 2.1. Kerangka Pikir}

\section{METODE PENELITIAN}

Penelitian ini dilakukan pada perusahaan Manufaktur yang terdaftar di BEI periode 20122017. Data yang digunakan terdiri atas beberapa rasio keuangan diperoleh melalui laporan tahunan (www.idx.co.id).

Tabel 1 . Pengambilan Sampel

\begin{tabular}{|l|c|}
\hline \multicolumn{1}{|c|}{ Kriteria } & Jumlah \\
\hline $\begin{array}{l}\text { Perusahaan yang menerbitkan annual report dan } \\
\text { laporan keuangan dari tahun 2012-2017 }\end{array}$ & 21 \\
\hline $\begin{array}{l}\text { Jumlah perusahaan X jumlah tahun pengamatan } \\
\text { (pooling data) }\end{array}$ & 126 \\
\hline
\end{tabular}

Sumber : Data diolah, 2018

Dalam penelitian ini dapat dibentuk persamaan :

$\mathbf{Y}=\mathbf{a}+\mathbf{b}_{1} \mathbf{X}_{1}+\mathbf{b}_{2} \mathbf{X}_{2}$

Keterangan :

Y : Profitabilitas

a : Konstanta, merupakan nilai terikat yang dalam hal ini adalah Y pada saat variabel bebasnya adalah 0

$(\mathrm{X} 1, \mathrm{X} 2=0)$

b1 : Koefisien regresi berganda antara variabel bebas $\mathrm{X}_{2}$ terikat $\mathrm{Y}$, apabila variabel bebas $\mathrm{X}_{2}$ dianggap konstan

b2 : Koefisien regresi berganda antara variabel bebas $\mathrm{X}_{2}$ terikat $\mathrm{Y}$, apabila variabel bebas $\mathrm{X}_{1}$ dianggap konstan

$\mathrm{X} 1 \quad$ : Perputaran persediaan

$\mathrm{X} 2$ : Perputaran Piutang

Pengujian hipotesis dilakukan dengan membandingkan tsatistik dengan ttabel (Wati, 2017).

\section{ANALISIS DATA \\ Hasil Regresi Linier Berganda}


Berdasarkan hasil perhitungan dengan SPSS 19 diperoleh persamaan regresi linier sebagaimana yang tersaji pada tabel 2 :

Tabel 2. Hasil Uji Regresi Linier Berganda

\section{Coefficients $^{\mathrm{a}}$}

\begin{tabular}{|c|c|c|c|c|c|c|c|c|}
\hline \multirow{2}{*}{\multicolumn{2}{|c|}{ Model }} & \multicolumn{2}{|c|}{$\begin{array}{l}\text { Unstandardized } \\
\text { Coefficients }\end{array}$} & \multirow{2}{*}{\begin{tabular}{|c|}
$\begin{array}{c}\text { Standardized } \\
\text { Coefficients }\end{array}$ \\
Beta
\end{tabular}} & \multirow[b]{2}{*}{1} & \multirow[b]{2}{*}{ Sig. } & \multicolumn{2}{|c|}{$\begin{array}{l}\text { Collinearity } \\
\text { Statistics }\end{array}$} \\
\hline & & B & Std. Error & & & & Tolerance & VIF \\
\hline \multirow[t]{3}{*}{1} & (Constant) & ,125 & ,022 & & 5,672 &, 000 & & \\
\hline & $\begin{array}{c}\text { Perputaran_Persediaa } \\
\mathrm{n}\end{array}$ &,- 009 & ,004 &,- 169 & $-2,154$ & ,033 & ,980 & 1,020 \\
\hline & Perputaran_Piutang & ,003 &, 001 & ,457 & 5,824 & ,000 & ,980 & 1,020 \\
\hline
\end{tabular}

a. Dependent Variable: Profitabilitas

Sumber: Data sekunder diolah dengan SPSS Versi 19,(2018)

Berdasarkan koefisien regresi untuk variabel $\mathrm{X}_{1}$ (Perputaran Persediaan) bernilai negatif menunjukkan hubungan yang berlawanan antara $\mathrm{X}_{1}$ (Perputaran Persediaan) dan $\mathrm{Y}$ (Profitabilitas). Nilai koefisien regresi variabel $\mathrm{X}_{1}$ (Perputaran Persediaan) sebesar 0.009 mengandung arti untuk setiap penurunan perputaran persediaan sebesar satu satuan akan menyebabkan meningkatnya Y (profitabilitas) sebesar 0.009 begitu pula sebaliknya, dengan asumsi bahwa variabel independen yang lain dalam model regresi adalah tetap atau tidak berubah. Koefisien regresi untuk variabel $\mathrm{X}_{2}$ (Perputaran Piutang) bernilai positif menunjukkan adanya hubungan yang searah antara $\mathrm{X}_{2}$ (Perputaran Piutang) dan $\mathrm{Y}$ (Profitabilitas), berarti semakin menigkatnya nilai $\mathrm{X}_{2}$ (Perputaran Piutang) maka akan meningkatkan $\mathrm{Y}$ (Profitabilitas). Nilai koefisien regresi variabel $\mathrm{X}_{2}$ (Perputaran Piutang) sebesar 0.003 mengandung arti untuk setiap kenaikan perputaran piutang sebesar satu satuan akan menyebabkan meningkatnya $\mathrm{Y}$ (profitabilitas) sebesar 0.003 , begitu pula sebaliknya jika perputaran piutang $\left(\mathrm{X}_{2}\right)$ menurun satu satuan maka akan menurunan profitabilitas perusahaan sebesar 0.003 .

\section{Hasil Uji t}

Uji t dilakukan untuk melihat besarnya pengaruh dan tingkat signifikan setiap variabel independen yang berskala rasio terhadap variabel dependen dilihat dari nilai signifikansi dari setiap variabel independen pada persamaan regresi. Hasil uji t pada penelitian ini disajikan pada tabel 3 berikut ini :

Tabel 3. Hasil Uji Statistik t

Coefficients $^{\mathrm{a}}$

\begin{tabular}{|c|c|c|c|c|}
\hline Model & $\mathrm{t}$ hitung & Sig. & A & Keterangan \\
\hline (Constant) & 5.672 & .000 & & \\
\hline Perputaran_Persediaan & -2.154 & .033 & 0.05 & Berpengaruh signifikan \\
\hline Perputaran_Piutang & 5.824 & .000 & 0.05 & Berpengaruh signifikan \\
\hline
\end{tabular}

Sumber : Data sekunder diolah dengan SPSS Versi 19, (2019) 


\section{JURNAL AKUNTANSI, Vol. 8, No. 2, November (2019)}

Untuk perputaran persediaan diketahui nilai $t_{\text {hitung }}$ sebesar 2.154 dengan sig $0.033<(\alpha)$ 0.05 atau dengan taraf signifikansi kurang dari 0.05 atau sebesar 0.033 maka $\mathrm{H}_{0}$ berhasil ditolak berarti bahwa perputaran persediaan berpengaruh signifikan terhadap profitabilitas perusahaan. Untuk perputaran piutang diketahui nilai $t_{\text {hitung }}$ sebesar 5.824 dengan sig $0.000<(\alpha) 0.05$ atau dengan taraf signifikansi lebih dari 0.05 atau sebesar 0.000 maka $\mathrm{H}_{0}$ berhasil ditolak berarti bahwa perputaran piutang berpengaruh signifikan terhadap profitabilitas perusahaan.

\section{Hasil Uji F}

Dari hasil pengujian dengan menggunakan SPSS 19 didapat hasil uji F seperti yang tersaji berikut ini :

Tabel 4. Hasil Uji F

\begin{tabular}{|c|c|c|c|c|c|c|}
\hline \multicolumn{7}{|c|}{ ANOVA $^{b}$} \\
\hline & Model & $\begin{array}{l}\text { Sum of } \\
\text { Squares }\end{array}$ & $\mathrm{df}$ & Mean Square & $\mathrm{F}$ & Sig. \\
\hline 1 & Regression & ,292 & 2 & 146 & 21,470 &, $000^{\mathrm{a}}$ \\
\hline & Residual & ,836 & 123 & ,007 & & \\
\hline & Total & 1,127 & 125 & & & \\
\hline
\end{tabular}

a. Predictors: (Constant), Perputaran_Piutang, Perputaran_Persediaan

b. Dependent Variable: Profitabilitas

Sumber : Data sekunder diolah dengan SPSS Versi 19,(2019)

Dari hasil yang diperoleh nilai sig $<\alpha(0.000<0.05)$ maka $\mathrm{H}_{03}$ ditolak, yang artinya secara simultan terdapat pengaruh signifikan variabel perputaran persediaan dan perputaran piutang terhadap profitabilitas perusahaan. Berdasarkan hasil uji $\mathrm{F}$, nilai $\mathrm{F}$ yang diperoleh adalah sebesar 21.470 dengan tingkat sig 0.000 yang berarti nilai sig $<(\alpha) 0.05$ maka dapat disimpulkan bahwa seluruh variabel independen secara simultan memiliki pengaruh yang signifikan terhadap variabel dependen. Hasil penelitian membuktikan bahwa model regresi dalam penelitian ini dapat digunakan untuk memprediksi faktor yang mempengaruhi profitabilitas.

\section{Hasil Koefisien Determinasi}

Hasil uji koefisien determinasi $\left(\mathrm{R}^{2}\right)$ dengan menggunakan perhitungan SPSS 19 dari persamaan regresi disajikan pada tabel 5 dibawah ini:

\section{Tabel 5}

\section{Hasil Koefisien Determinasi}

\begin{tabular}{|c|c|r|r|r|c|}
\hline Model & $\mathrm{R}$ & $\mathrm{R}$ Square & $\begin{array}{c}\text { Adjusted R } \\
\text { Square }\end{array}$ & $\begin{array}{c}\text { Std. Error of } \\
\text { the Estimate }\end{array}$ & $\begin{array}{c}\text { Durbin- } \\
\text { Watson }\end{array}$ \\
\hline 1 &, $769^{\mathrm{a}}$ &, 512 &, 534 &, 84238 & 2,596 \\
\hline
\end{tabular}

a. Predictors: (Constant), Perputaran_Piutang, Perputaran_Persediaan

b. Dependent Variable: Profitabilitas

Sumber : Data sekunder diolah dengan SPSS Versi 19, (2018) 


\section{JURNAL AKUNTANSI, Vol. 8, No. 2, November (2019)}

Berdasarkan tabel 5 dapat diketahui nilai koefisien determinasi $\left(\mathrm{R}^{2}\right)$ sebesar 0.512 atau $51.2 \%$ artinya variabilitas variabel profitabilitas dapat dijelaskan oleh variabilitas variabel perputaran persediaan dan perputaran piutang sebesar $51.2 \%$, sedangkan sisanya $48.8 \%$ dijelaskan oleh variabel lain yang tidak dimasukkan dalam model regresi ini. Hal ini menunjukkan bahwa masih ada variabel lain di luar variabel perputaran persediaan dan perputaran piutang yang berpengaruh terhadap profitabilitas perusahaan.

\section{PEMBAHASAN}

\section{Pengaruh perputaran persediaan terhadap profitabilitas}

Dari hasil penelitian pada variabel perputaran persediaan $\left(\mathrm{X}_{1}\right)$ diperoleh nilai sebesar 2.154 dengan sig $0.033<(\alpha) 0.05$ atau dengan taraf signifikansi kurang dari 0.05 maka $\mathrm{H}_{0}$ berhasil ditolak berarti bahwa perputaran persediaan berpengaruh positif signifikan terhadap profitabilitas perusahaan. Dengan demikian hipotesis yang menyatakan perputaran persediaan berpengaruh positif signifikan terhadap profitabilitas profitabilitas terbukti. Hasil penelitian ini mendukung dari penelitian Rosyeni (2015) dengan judul "Pengaruh Perputaran Persediaan dan Perputaran Piutang Terhadap Profitabilitas Pada PT. Sinar Bangun Sejahtera", yang menunjukan bahwa perputaran persediaan berpengaruh positif terhadap profitabilitas perusahaan.

\section{Pengaruh perputaran piutang terhadap profitabilitas}

Dari hasil penelitian pada variabel perputaran piutang $\left(\mathrm{X}_{2}\right)$ diperoleh nilai 5.824 dengan sig $0.000<(\alpha) 0.05$ atau dengan taraf signifikansi kurang dari 0.05 atau sebesar 0.000 maka $\mathrm{H}_{0}$ berhasil ditolak berarti bahwa perputaran piutang berpengaruh positif signifikan terhadap profitabilitas pada perusahaan. Hasil penelitian ini mendukung dari penelitian Hesti Rahmasari (2012) dengan judul "Pengaruh penjualan dan perputaran piutang terhadap laba bersih pada perusahaan industri barang konsumsi BEI tahun 2012-2016.", yang menunjukan bahwa perputaran piutang berpengaruh positif terhadap profitabilitas perusahaan.

\section{Pengaruh perputaran pesediaan dan perputaran piutang terhadap profitabilitas}

Berdasarkan hasil uji $\mathrm{F}$, nilai $\mathrm{F}$ yang diperoleh adalah sebesar 21.470 dengan tingkat sig 0.000 yang berarti nilai sig $<(\alpha) 0.05$ maka dapat disimpulkan bahwa seluruh variabel independen yaitu perputaran persediaan dan perputaran piutang secara simultan memiliki pengaruh positif signifikan terhadap variabel dependen yaitu profitabilitas perusahaan. Hasil penelitian ini mendukung dari penelitian Rosyeni (2015) pada tahun 2015 dengan judul "Pengaruh Perputaran Persediaan dan Perputaran Piutang Terhadap Profitabilitas Pada PT. Sinar Bangun Sejahtera". Hasil penelitian menyimpulkan bahwa perputaran persediaan dan perputaran piutang berpengaruh positif signifikan terhadap profitabilitas perusahaan.

\section{PENUTUP}

Perputaran persediaan berpengaruh positif siginifikan terhadap profitabilitas perusahaan. Hasil penelitian ini menunjukkan bahwa salah satu faktor yang mempengaruhi besarnya profitabilitas adalah kondisi perputaran persediaan pada perusahaan itu sendiri. Semakin tinggi tingkat perputaran persediaan maka semakin besar pula profitabilitas yang akan diperoleh oleh perusahaan tersebut. Perputaran piutang berpengaruh positif signifikan terhadap profitabilitas pada perusahaan. Hal ini berarti perputaran piutang berperan langsung dalam mendukung peningkatan profitabilitas perusahaan. Perputaran persediaan dan perputaran piutang secara simultan memiliki pengaruh positif signifikan terhadap variabel dependen yaitu profitabilitas perusahaan. 


\section{REFERENSI}

Harahap, Sofyan Syafri. (2010). Teori akuntansi dan penerapannya. Trisakti: Jakarta Harahap, Sofyan Syafri. (2010). Teori akuntansi dan penerapannya. Trisakti: Jakarta Sugiyono. (2012). Metode Penelitian Manajemen : Pendekatan, Kuantitatif, Kualitatif, Kombinasi (Mixed Method), Penelitian Tindakan, Penelitian Evaluasi. Alfabeta: Bandung.

Riyanto, Bambang. (2010). Dasar - Dasar Pembelanjaan Perusahaan. Edisi Keempat. Gajah Mada: Yogyakarta.

Kun Muflihati \& Hening Widi Oetomo, (2014). Pengaruh Perputaran Kas, Piutang Dan Persediaan Terhadap Profitabilitas Perusahaan Pakan Ternak. Sekolah Tinggi Ilmu Ekonomi Indonesia (STIESIA) Surabaya.

Harmono. 2014. Manajemen Keuangan Berbasis Balanced Scorecard. Jakarta: Bumi Aksara.

Suarnami, Luh Komang, I Wayan Suwendra, dan Wayan Cipta. 2014.” Pengaruh Perputaran Piutang, Periode Pengumpulan Piutang Terhadap Profitabilitas Perusahaan Pembiayaan yang Terdaftar di Bursa Efek Indonesia (BEI) Tahun 2008-2012". e-Journal Bisma Universitas Pendidikan Ganesha. Universitas Pendidikan Ganesha. Singaraja. Vol. 2.

Horne, Van dan Wachowicz. 2013. Prinsip-prinsip Manajemen Keuangan. Edisi Indonesia. Penerbit Salemba Empat. Jakarta.

Keown, Arthur J. et. All. 2010. Manajemen KeuanganPrinsip dan Penerapan. PT INDEKS.

Sartono, Agus, R. 2010. Manajemen keuangan Teori dan Aplikasi. Edisi Keempat. Yogyakarta;BPFE. Harrison, Jr, Walter T, Homgren T Charles, Thomas William C, dan Suwardy

Themin, 2013. Akuntansi Keuangan, Jilid2, Edisi 8, Erlangga, Jakarta.

Wati, L.N. 2017. Metodologi Penelitian Terapan Bisnis: Aplikasi SPSS, EVIEWS, SmartPLS, dan AMOS. Bandung: Mujahid Press. 